\title{
Ilona Mikołajczak
}

Instytut Filologii Polskiej Uniwersytetu im. Adama Mickiewicza w Poznaniu

\section{Neologizmy artystyczne jako przedmiot badań nad poprawnością językową (na materiale wybranych utworów Jacka Dukaja)}

W literaturze przedmiotu utrwaliło się przekonanie, że ze względu na pełnienie funkcji estetycznej współczesne utwory literackie nie stanowią odpowiedniego materiału do badań związanych z zagadnieniami kultury języka. Zarówno Witold Doroszewski, jak i Andrzej Markowski uważają, że język pisarzy nie powinien stanowić wzorca normatywnego [zob. Markowski 2005: 48, 52]. Podczas gdy autor Kryteriów poprawności językowej wyklucza kryterium literacko-autorskie, wskazując na uwarunkowania historyczne, geograficzne i socjologiczne pisarzy, twórca koncepcji dwupoziomowej normy językowej, mając na uwadze rozmaite typy stylizacji, odmawia im udziału w specjalnej grupie uzualnej traktowanej jako autorytet kulturalny. Podobna selekcja występuje w przypadku samodzielnych elementów systemu języka - z rozważań poświęconych ocenie normatywnej neologizmów Hanna Jadacka „programowo" eliminuje neologizmy artystyczne [Jadacka 2005: 98].

Tymczasem literatura piękna od wieków była uważana za niewyczerpane źródło wiedzy o języku. Co więcej, jej udział w formułowaniu założeń kultury języka cieszy się długoletnią tradycją. Stanisław Szober w 1937 roku opierał ocenę normatywną m. in. na języku literackim pisarzy XIX i XX wieku, zresztą było to zjawisko typowe jeszcze w latach 50. [Markowski 2005: 29, 115]. Mimo iż neologizmy artystyczne nigdy nie uchodziły za szczególnie ekspansywne, a ich wkład w leksykę ogólną określa się jako znikomy [zob. Kurkowska, Skorupka 2001: 28, 94], nie można mieć żadnych wątpliwości co do ich wpływu na współczesnego odbiorcę. Skoro bowiem zakładamy, że utworzone przez poetów czy pisarzy nowe elementy leksykalne zasadniczo nie różnią się od tych pozostałych, również stanowiąc odzwierciedlenie współczesnych tendencji słowotwórczych oraz że stopień ich rozumienia wynika z oparcia 
w istniejącym systemie leksykalnym [Kurkowska, Skorupka 2001: 81], powinniśmy także założyć, że mają taką samą - lub podobną - moc oddziaływania na użytkowników języka. Dlatego też istnieje stała konieczność bliższego przyglądania się im, a nawet poddania ich ocenie normatywnej.

Nim jednak rozpoczniemy weryfikację kryteriów oceny poprawnościowej $^{1}$ - bo są one niewątpliwie niezbędnym narzędziem do niej służącym należałoby poprzedzić ją pewnym spostrzeżeniem. Twórczość nie wszystkich pisarzy czy poetów nadaje się do ukazania mechanizmów kodyfikacji normatywnej. Wynika to nie tylko z faktu, że autorzy dzieł literackich nie są w równym stopniu aktywni słowotwórczo, lecz również z różniącej ich popularności. Wskazane jest więc wybieranie takich utworów, które mają przynajmniej teoretycznie możliwość dotarcia do szerokiego grona odbiorców, a co za tym idzie - wywierania największego wpływu. Co więcej, warto zauważyć, że neologizmy, których znaczenie nie jest klarownie przedstawione, mają największą zdolność ukazywania niuansów kodyfikacji normatywnej. Wymagają one bowiem sięgnięcia po ubogi, lecz nierzadko jedyny dostępny kontekst, mianowicie skupienia się na użytych cząstkach czy leksemach, a nie objaśniającym ich opisie. Nie bez powodu zatem badacze stylu artystycznego swoje wnioski wyciągają z analizy twórczości poetyckiej, chociażby Bolesława Leśmiana [zob. Kurkowska, Skorupka 2001: 81-94]. Dopiero przyjęcie takich założeń pozwala nam na wytypowanie odpowiedniego przedstawiciela literatury pięknej.

Za twórcę w dużej mierze odpowiadającego tym zaleceniom można uznać autora wielokrotnie nagradzanej powieści Lód [Budzyńska 2009: 42-45], pisarza science fiction, Jacka Dukaja, który ma na swoim koncie 14 powieści oraz ponad 30 opowiadań [zob. Bio, dostęp: 2017]. Rzecz jasna miarą przydatności jego prozy jest nie liczba otrzymanych nagród czy pozycji w dorobku literackim, lecz uznanie zdobyte za ich sprawą. Pozwoliło ono bowiem na pojawienie się w kanonie lektur szkolnych opowiadania zatytułowanego Katedra, a bezspornie wpisanie nawet krótkiej formy epickiej na listę lektur obowiązkowych sprzyja rozpowszechnianiu dzieł danego autora. Według najnowszej podstawy programowej do szkoły średniej Dukaj został postawiony w jednym rzędzie z Olgą Tokarczuk, Antonim Liberą czy Andrzejem Stasiukiem jako jeden z niewielu reprezentantów literatury współczesnej [zob. Podstawa... 2018]. Oznacza to, że jego twórczość cieszy się aprobatą w środowisku naukowym, co jest dość nietypowe, biorąc pod uwagę pokutującą jeszcze do niedawna opinię

1 Jako wyjściową przyjmiemy klasyfikację według Andrzeja Markowskiego [zob. Markowski 2005: 48-55]. 
o niskiej wartości artystycznej utworów należących gatunkowo do fantastyki naukowej [Budzyńska 2009: 42]. Również w kwestii tworzenia form niedających się łatwo scharakteryzować Dukaj spełnia nasze wymagania. Jak twierdzi jedna z recenzentek, pisząc o Innych pieśniach i Perfekcyjnej niedoskonałości, „lektura pierwszych kilkudziesięciu co najmniej stron to mozolne przyswajanie słownika najważniejszych pojęć, jakie rządzą światem przedstawionym, niezbędnych terminów, których sens nie jest wyłożony, lecz trzeba go dociekać z mniej lub bardziej skąpego kontekstu" [Kobielska: 2010].

Jednakże do celów naszych badań nie posłuży ani Lód, ani zaproponowana w podstawie Katedra - w przeciwieństwie do innych dzieł absolwenta filozofii nie są one zbyt bogate w nowe środki leksykalne. Warto natomiast byłoby przyjrzeć się tym utworom, które uchodzą za najbardziej innowacyjne w tym zakresie. Mowa o wyżej wymienionej Perfekcyjnej niedoskonałości [Dukaj 2014] oraz zamieszczonej w zbiorze Król bólu minipowieści Linia oporu [Dukaj 2010]. W obu tych pozycjach znajdujemy wiele różnorodnych neologizmów słowotwórczych, wykorzystujących rozmaite morfemy czy będących różnymi częściami mowy, a nawet próbę utworzenia nowego rodzaju gramatycznego za pomocą końcówki fleksyjnej -u. Jak słusznie zauważa Przemysław Czapliński, przywołując Perfekcyjną niedoskonałość w swoich badaniach nad tzw. nowoczesnością, „Phoebe [typ postaci występujący w powieści - I.M.] nie są ani męskie, ani żeńskie, ani obojnacze, ani nijakie - są postpłciowe. Dlatego pisarz musiał naruszyć polską fleksję" [Czapliński 2011: 237]. Ponieważ jednak zapowiedzieliśmy weryfikację kryteriów oceny poprawności językowej neologizmów artystycznych w ogóle, skupimy się na łatwiejszych do odczytania formach. Co nie oznacza, że do Dukajowskiego eksperymentu nie powrócimy.

Pierwszym kryterium omawianym w opracowaniu Markowskiego jest kryterium wystarczalności, rozumiane jako aprobowanie neologizmów mających na celu pełnienie funkcji ekspresywnej lub nominatywnej, czyli nazwanie nowego desygnatu. W tym miejscu warto zaznaczyć, że fantastyka naukowa naturalnie generuje potrzebę takiego tworzenia, „ma bowiem nazywać świat przez autora wymyślony, ale zgodny z jakąś pseudonauką. Neologizmy dokonują tu pseudoterminologizacji tekstu - a więc jego pseudonaukowienia" [Bajerowa 2003: 87]. Nic więc dziwnego, że nowa rzeczywistość wymaga od twórcy tego specyficznego gatunku literackiego konstruowania form przeznaczonych głównie do nazywania jej nowych elementów. Neologizmy takie jak wyżej przywołane phoebe [Dukaj 2014: 9], oznaczające nowy, niedający się opisać żadnym ze znanych słów typ bytu, czy chociażby fren, definiowany w powieści jako „ośrodek życia psychicznego” [Dukaj 2014: 8], który na podobieństwo 
systemu operacyjnego można sczytać, podzielić, poddać aktualizacji, zapisać w dowolnej chwili lub pomniejszyć o zbędne dane, są właśnie takimi formami.

Nie świadczy to jednak o nieistnieniu wyrazów, które mogłyby zostać uznane za niepoprawne, biorąc pod uwagę kryterium wystarczalności. Należy do nich np. przyimek zmiędzy, występujący w takim oto kontekście: „Ludovic, już ćwierć-Paweł, wyrywa zmiędzy dachówek chwasty i zaczyna je splatać w wianki i łańcuchy"2 [Dukaj 2010: 114]. Użyty leksem nie różni się znaczeniowo od spomiędzy, a przywoływany w tekście dach również nie wykazuje żadnych cech szczególnych. Nawet gdybyśmy próbowali założyć, że zastępuje inny przyimek - między, jego połączenie składniowe temu przeczy. Mimo iż w języku polskim wymiana afiksalna jest częstym i akceptowanym zjawiskiem [Jadacka 2005: 120], szczególnie gdy jej rezultaty wydają się ekonomiczniejsze oraz precyzyjniejsze, innowacja ta nie spełnia naszego podstawowego kryterium. Podobne konkluzje pojawiają się po bliższym przyjrzeniu się czasownikowi podkicały. „Małe futrzaste demony podkicaly na próg chatki” [Dukaj 2010: 132] - metaforycznie opisuje króliki główny bohater Linii oporu, Paweł Kostrzewa. Tymczasem z omawianego tekstu nie wynika, żeby tak scharakteryzowane zwierzęta miały do pokonania wyższy od nich stopień czy przeszkodę, na co wskazywałaby zastosowana wymiana przedrostka. Reasumując, kryterium wystarczalności może skutecznie służyć ocenie normatywnej innowacji językowych w dziele literackim.

Właściwie kryteria wystarczalności, ekonomiczności i estetyczne zawierają się poniekąd w jednym - kryterium funkcjonalności. Staje się ono wówczas kryterium zbędnym, pewnym naddatkiem terminologicznym. Główną przyczyną takiego zjawiska jest nie tyle istnienie rozmaicie zbudowanych neologizmów w tekście językowym, ile przede wszystkim pełnienie przez nie określonej funkcji w tekście. Jak sama nazwa wskazuje, to właśnie spełnianie różnych potrzeb nadawczych czy odbiorczych, poparte użyciem w udanym kontekście, winno stanowić miernik poprawności danego środka leksykalnego w przypadku dzieł literackich.

Za odpowiednie neologizmy powinniśmy więc uznać te, które np. dzięki poprawnej budowie nie przysparzają czytelnikowi większych problemów ze zrozumieniem znaczenia. Co ważne, nie należy obstawać przy założeniu, że nowo utworzony leksem powinien odzwierciedlać zasady normatywne całościowo. Czytelnik nie ma trudności ze stwierdzeniem, że sztandarzątka ${ }^{3}$ to nie-

2 Wszystkie wyróżnienia w przytoczeniach - I.P.

3 „Andrzej dopada chłopca zajętego prezentem od Pawła, wojska polskie i litewskie rozwinęły linie od kuchni do tylnych drzwi, rycerstwo Zachodu stoi pod schodami, powiewają 
wielkie chorągwie, reprezentujące jednostki wojskowe ${ }^{4}$ (wskazuje na to przywołany cytat), mimo dwóch ważnych czynników. Po pierwsze, nowy desygnat nie został przedstawiony w formie opisu; możemy się jedynie domyślać, że forma tej innowacji odzwierciedla miniaturową wielkość części plastikowego zestawu zabawkowego „Grunwald 1410”. Po drugie, zgodnie z normą nazwy utworzone za pomocą rozszerzonego wariantu przyrostka wyspecjalizowanego w tworzeniu zdrobnień, sufiksu -ątko, teoretycznie dotyczą istot młodych, nie przedmiotów, co więcej, powinny pochodzić od wyrazów kończących się na -e [Markowski, red. 2004: 1537 (-ątko)]. Na podstawie tego założenia moglibyśmy stwierdzić, że zamieszczone w liczbie mnogiej sztandarzatko jest zdrobnieniem istoty ożywionej, zwanej sztandarze, co nie ma żadnego uzasadnienia ani w świecie przedstawionym ${ }^{5}$, ani w istniejącym systemie leksykalnym. Nowo powstały wyraz spełnia jednak swoją funkcję, chociaż nie wykazuje pełnej zgodności z normą językową.

Dotychczas uznaliśmy za poprawne neologizmy odzwierciedlające zabiegi słowotwórcze języka ogólnego. Tymczasem omawiając teksty literackie, musimy zauważyć, że one także charakteryzują się pewną systemowością, zawierającą się w najczęściej wykorzystywanych przez autora sposobach tworzenia innowacji uzupełniających. Takie rozumienie kryterium estetycznego sytuuje je na pierwszym miejscu w klasyfikacji kryteriów oceny poprawnościowej, co pozwala na usankcjonowanie istnienia większości przydatnych form, nawet jeśli nie są one aprobowane przez pozostałe kryteria. Analizując twórczość Dukaja, nietrudno zauważyć, że pisarz ma predylekcję do nietypowego wykorzystywania znaków pisarskich, w tym łączenia wyrazów za pomocą dywizu. Dzięki tej wiedzy innowacja uzupełniająca meta-fizyka, definiowana przez powieściowy słownik jako: „Nauka o zmienianiu praw fizyki. Przewiduje warunki konieczne dla odkraftowania inkluzji o danej charakterystyce (liczbie wymiarów, wielkości stałych fizycznych, liczbie i własnościach cząstek elementarnych etc.)" [Dukaj 2014: 350], ma uzasadnienie nie tylko w kryterium wystarczalności - nie jest bowiem znaną od starożytności metafizyką poddaną neosemantyzacji - lecz także w kryterium estetycznym. Jeśli jednak chcemy wyrazić wątpliwość co do jego miejsca w hierarchii, powinniśmy przedstawić

sztandarzątka, na schodach wyrósł nawet miniaturowy lasek, piechota roi się z drzewa jak korniki" [Dukaj 2010: 39].

4 Wszelkie uwagi obejmujące różnice znaczeń leksykalnych oraz nacechowanie wyrazów zostały sformułowane na podstawie internetowego słownika języka polskiego [zob. Słownik..., dostęp: 2017].

5 Wnikliwy badacz funkcji poetyckiej mógłby stać na stanowisku, że rolą tej innowacji w przywołanym cytacie jest metaforyczne wzmocnienie wszechobecnego ożywienia. 
inny przykład - omówiona wyżej innowacja sztandarzątka idealnie się do tego nadaje, gdyż na pierwszy rzut oka trudno uzasadnić jej istnienie.

W języku polskim istnieje bowiem wyraz sztandarek, zdrobnienie zgodne z normą językową dla derywatu od leksemu sztandar. Jednak wystąpienie w tym samym tekście innej formy, cherubiatka [Dukaj 2010: 215], wskazuje na powstanie kolejnego autorskiego wzorca tworzenia neologizmów, tym razem zdrobnień. Nie wgłębiając się w szczegóły normatywne - cherubiątka również nie wykazują pełnej zgodności z normą i mają swój odpowiednik w polszczyźnie - należy zaznaczyć, że kryterium estetyczne uzasadnia istnienie tych innowacji w zupełności.

Większość badaczy radzi, by przy omawianiu neologizmów artystycznych odwoływać się do kategorii gatunku literackiego, w którym one występują [Kurkowska, Skorupka 2001: 94]. Niewątpliwie zapoznanie się z charakterystyką poetyki stosowanej w danym typie utworów sprzyja lepszemu rozumieniu ich funkcji, jednak jeśli zakładamy ekstensję wykraczającą poza dzieło literackie, nie jest to konieczne - neologizmy mogą przeniknąć do tekstów różnego rodzaju. Co więcej, analiza oparta na przynależności gatunkowej neologizmów rodzi te same wnioski, co analiza jej pozbawiona - zrozumiałość każdego neologizmu zależy od użytych cząstek oraz przedstawionych kontekstów. Takie konkluzje wynikają z naświetlenia mechanizmów słowotwórczych dokonanego przez Ryszarda Handkego w artykule poświęconym prozie Stanisława Lema [zob. Handke 1989: 225-239]. Ponadto zbytnie skupianie się na przywołanej kategorii może prowadzić do znaczących uproszczeń. Mianowicie, cytowana wyżej opinia Czaplińskiego wskazuje na konieczność utworzenia nowego rodzaju gramatycznego w Dukajowskiej powieści. Również inni recenzenci, np. dzięki dokonaniu eliminacji negatywnej samogłosek już zagospodarowanych $w$ języku polskim, zauważają, że zaadaptowanie końcówki $-u$ było jedynym logicznym wyjściem z tej sytuacji [zob. Tako rzeklu phoebe 2010]. Nim jednak przytoczymy ocenę skrajnie odmienną, skrótowo przedstawmy przynajmniej kilka innowacji uzupełniających będących przedmiotem naszych rozważań. Najliczniejszą grupę, obejmującą ponad 200 konstrukcji, stanowią czasowniki czasu przeszłego: opowiedziału, zerknęłu, weszłum, rzuciłum, wędrowatuśmy, zbieratuśmy, dału się ${ }^{6}$ [Dukaj 2014: 29, 12; 2010: 211, 212, 213, 212]. Pojawiają się również formy trybu przypuszczającego: mogtubyś, postałubyś się, poczytałobu ${ }^{7}$ [Dukaj 2014: 133, 222]. Mamy też do czynienia z różnego rodzaju zaimkami: osobowymi onu, пи i wu [Dukaj 2014: 222, 12,

6 Ta innowacja zostanie omówiona w dalszej części artykułu.

7 Por. poprzedni przypis. 
170], dzierżawczymi jenu [Dukaj 2014: 382] i moju [Dukaj 2010: 214], nieokreślonym jakukolwiek [Dukaj 2014: 15], wskazującymi tenu i tamtu [Dukaj 2014: 245, 124], przeczącym żadnu [Dukaj 2014: 204], przymiotnym którenu [Dukaj 2010: 212] oraz liczebnikami: jednu, jednum, a nawet samojednu [Dukaj 2014: 58, 27; 2010: 214]. W tekstach nie brak przymiotników, np.: niezdecydowanu, nagu [Dukaj 2010: 216, 211], a także rzeczowników, odmieniających się za pomocą wymienionej końcówki, przyjmujących formy: w mianowniku Zamoysku, w miejscowniku Patrickum, w celowniku żonu [Dukaj 2014: 382, 148, 382]. Jak widać, Dukaj podjął próbę utworzenia nowego rodzaju gramatycznego wraz z wszelkimi tego konsekwencjami. W tekstach nie znalazły się jedynie formy 2. os. 1 p. i $1 \mathrm{~m}$. oraz 3. os. $1 \mathrm{~m}$. Oznacza to, że wszelkie pozostałe neologizmy były mu potrzebne do pełnienia różnych funkcji, przede wszystkim zaznaczenia, że pojawiająca się w tekście wypowiedź dotyczy postaci „postludzkiej" lub jest przez nią wypowiadana. Jednakże nie wszyscy recenzenci dostrzegli zarówno konieczność utworzenia nowego rodzaju gramatycznego, jak i dominującą w jego tworzeniu konsekwencję:

Fantastyka jako składowa część literatury popularnej, współistniejąca z tego typu filmami, wykształciła wcale liczną grupę swoich odbiorców i naśladowców. Współcześnie wyobraźnia twórców jest wyraźnie zależna od filmu: dotyczy to konstrukcji fabuły swobodnego, ,cudownego”, bo nie uzasadnionego logicznie łączenia elementów, także ostrego, pełnego przeskoków i luk montażu. Bo fabuła jest tylko swobodną grą wyobraźni. Postacią pierwszoplanową tego typu w literaturze stał się u nas - uważany za następcę Lema - Jacek Dukaj. [...] Eksperymenty stylistyczne i językowe Lema, jego neologizmy, znaczone humorem i ironią, zmieniają się u następców w leksykalne i frazeologiczne dziwactwa. Bo jak rozumieć zniekształcone formy gramatyczne we fragmencie Perfekcyjnej niedoskonałości: pierwszej tercji progresu? Rzecz dzieje się w XXIX wieku, likwidacji ulegają nie tylko czas i przestrzeń, ale i zasady gramatyki $[\ldots]$. Co oznaczają zniekształcone formy fleksyjne - nowy rodzaj gramatyczny na określenie języka robotów? Przewidywany zanik różnic ze względu na płeć, a może także przewidywany zanik płci w XXIX wieku? Piętrzenie nieobjaśnianych pojęć i terminów, stawianie obok siebie Tutenchamona, De la Roche'a i Adama Zamojskiego [sic] ${ }^{8}$, cesarza i Artificial Reality, eksponuje chaos po kosmicznej katastrofie, ale nic z owego faktu nie wynika.

8 Krytyk literacki nie tylko przypisał rodzaj męski rzeczownikom właściwym nowemu rodzajowi gramatycznemu w prozie Dukaja, lecz również niepoprawnie przytoczył nazwisko głównej postaci, Adama Zamoyskiego. 
[...] Niesamowitość powstaje z samego przekroczenia granic zdrowego rozsądku. Co się za tym kryje, prócz pustego efektu? [Burkot 2010: 384-385]

Oznacza to mniej więcej tyle, że powołując się na istniejącą tradycję literacką, badacz skrytykował nie tylko funkcję poetycką powstałych neologizmów, ale też nie zauważył ich rzeczywiście istniejącej funkcji komunikatywnej. Ponadto nie dostrzegł podejmowanej przez Dukaja i konsekwentnie realizowanej próby nadania nowemu rodzajowi gramatycznemu systemowego charakteru: eksploatowanej końcówki oraz utworzenia większości niezbędnych części mowy. Takie stanowisko świadczy o dwóch postawach krytyka: wobec dzieła literackiego oraz wobec jego języka. Nie da się ukryć, że współczesną fantastykę postrzega on pejoratywnie, jako oderwaną od zasad logiki i estetycznie odbiegającą jakościowo od znanej mu tradycji, której kontynuacji oczekuje.

Trzeba zauważyć, że podczas omawiania innowacji językowych pochodzących z dzieła literackiego opieramy się niemalże wyłącznie na kryteriach uznawanych za wewnątrzjęzykowe. Trudno bowiem mówić o efektywnym wykorzystywaniu w kontekście neologizmów choćby kryterium uzualnego, mając pełną świadomość niewielkiego ich rozpowszechnienia oraz słusznego przypisania przywołanemu miernikowi statusu postkryterium [Jadacka 2005: 120]. Nie oznacza to, że dokonując oceny przydatności innowacji uzupełniającej, zupełnie nie możemy oprzeć się na uzusie. $Z$ taką sytuacją mamy do czynienia, gdy wyraz lub człon pojawił się w omawianym tekście, lecz jego autorstwa nie można przypisać twórcy literackiemu, ponieważ dane słowo istnieje już w innych, wcześniejszych tekstach, a nawet w innej formie ${ }^{9}$, jednak nie zostało zarejestrowane przez słowniki ogólne. Przykładem niech będzie przymiotnik postludzki, którego użycie zanotowano na długo przed 2004 rokiem (pierwsze wydanie Perfekcyjnej niedoskonałości), bo już w roku 1988 [zob. Postludzki, dostęp: 2017]. Każde kolejne pojawienie się neologizmu w dziele literackim będzie sankcjonowało jego użycie.

$\mathrm{Z}$ kolei kryterium narodowe nie powinno być brane pod uwagę $\mathrm{w}$ ocenie dzieła literackiego, gdyż świat w nim przedstawiony, a co za tym idzie prezentowane zjawiska językowe są z nim nierozerwalnie związane i fakt, że np. autor umiejscowił akcję powieści w przyszłości, gdy język angielski jest językiem międzynarodowym, więc jego wpływ na język ojczyzny jest znaczący, nie powinien być przedmiotem oceny. To dodatkowa informacja, swoista funkcja metajęzykowa, która może być pełniona przez tekst literacki.

9 Na przykład gdy wyraz ma charakter internacjonalistyczny. 
Czy w takim razie można mówić o błędzie językowym w tekście literackim? I tak, i nie. Jeśli uzależnimy naszą opinię od intencji nadawcy czy kompetencji odbiorcy, jesteśmy skazani na stałą i niekoniecznie trafną spekulację. Nie jesteśmy bowiem w stanie stwierdzić, czy budząca wątpliwości innowacja językowa powstała w wyniku celowego zabiegu autora, czy też nie - co stanowi podstawowe znamię błędu językowego, czy i w jakim stopniu odbiorcy dzieła dostrzegają istniejącą w nim systemowość i mają świadomość normy na tyle, by dostrzec jej naruszenie, oraz jaką postawę wobec języka przyjmują. Natomiast odwołując się do kryteriów oceny poprawności językowej, nierzadko możemy dostrzec sprzeczność między wnioskami sformułowanymi na ich podstawie.

Rozwiązaniu problemu winna przysłużyć się hierarchia kryteriów. W przypadku dzieła literackiego logiczne wydawałoby się umiejscowienie na pierwszym miejscu kryterium estetycznego. Tylko taka hierarchia pozwala na usankcjonowanie form typu zmiędzy, sztandarzatka i cherubiatka. Przyimek ma zwrócić uwagę odbiorcy, od jego postawy wobec roli języka literackiego zależy ocena innowacji językowej. Z kolei zastosowane zdrobnienia mają dodatkowo wzmocnić rangę modelu słowotwórczego wybranego przez autora, podkreślić istniejącą $\mathrm{w}$ tekście systemowość. Jedynymi wyżej przywołanymi innowacjami, które nie znajdują oparcia w kryterium estetycznym, są formy poczytatobu oraz dału się, występujące jednokrotnie, będące zaprzeczeniem mechanizmów morfologicznych, które posłużyły Dukajowi do utworzenia podobnych form czasownika. Inne przykłady trybu przypuszczającego: mogłubyś czy posłałubyś opierają budowę na zamieszczeniu nowego morfemu w miejscu, gdzie wykładnikiem rodzaju męskiego jest zero morfologiczne, natomiast w formach rodzaju żeńskiego czasowników występuje morfem - $a$. Tak więc omawiana innowacja wydaje się jedynie pomyłką, niezgodną z regułami ustalonymi $\mathrm{w}$ tekście, nieumyślnym błędem autora lub redaktora. Z kolei drugi neologizm pojawił się w takim oto kontekście: „Strażnik Gaju, którenu nie dału się zobaczyć ani usłyszeć, a jedynie wyśnić, odpowiadału jak Dziwo: jutro, pojutrze, za tysiąc lat, wczoraj" [Dukaj 2010: 212]. To samo zdanie nietraktujące o istotach postludzkich w różnych wersjach rodzajowych polszczyzny brzmiałoby tak: „Strażnik Gaju, którego nie dało się / której nie dało się / którego nie dało się zobaczyć, ani usłyszeć, a jedynie wyśnić, odpowiadał / odpowiadała / odpowiadało jak Dziwo: jutro, pojutrze, za tysiąc lat, wczoraj”. Okazuje się, że innowacja dału się na gruncie polszczyzny nie ma uzasadnienia, gdyż nie istniała konieczność jej utworzenia - w języku polskim w każdym przykładzie występuje jako bezosobowa forma czasownika, niezdradzająca płci wykonawcy. Jej pojawienie się jest więc bezcelowe. 
$* * *$

Analizując neologizmy artystyczne pod kątem poprawności językowej, powinniśmy oprzeć się na trzech kryteriach w następującej dwustopniowej hierarchii:

a) kryterium estetyczne - które spełniają wszystkie neologizmy pełniące funkcję poetycką oraz z definicji neologizmy spełniające pozostałe kryteria, gdyż zostały one uznane za przydatne w tekście,

b) kryterium wystarczalności (neologizmy spełniające funkcję nominatywną) oraz kryterium ekonomiczności (wszelkie formy uniwerbizowane oraz neologizmy podkreślające systemowość tekstu literackiego).

W razie potrzeby można sięgnąć po kryterium uzualne. Nieuzasadnione wydaje się korzystanie z kryterium narodowego oraz kryterium funkcjonalności, które z uwagi na fakt, że neologizmy artystyczne są zawsze badane pod kątem użycia w tekście, stałoby się jedynie naddatkiem terminologicznym, automatycznie spełnianym przez innowacje aprobowane dzięki pozostałym kryteriom.

Ocena normatywna neologizmów artystycznych wymaga od badacza zagłębienia się w tekst literacki, dostrzeżenia rządzących nim mechanizmów lub sięgnięcia po rozmaite konteksty. Należy jej jednak dokonywać ostrożnie, przyjmując stanowisko deskryptywne, mając na uwadze przede wszystkim dobro odbiorcy, który już niedługo na etapie szkoły średniej spotka się z Dukajowską prozą, zdolną do wywierania wpływu na jego świadomość i zachowania językowe.

\section{Bibliografia}

Bajerowa Irena (2003), Zarys historii języka polskiego 1939-2000, Wydawnictwo Naukowe PWN, Warszawa.

Bio, w: Jacek Dukaj, http://www.dukaj.pl/bio [dostęp: 22 października 2017].

Budzyńska Natalia (2009), Jacek Dukaj - Fantastyczne światy, „Przewodnik Katolicki”, nr 1, s. 42-45.

Burkot Stanisław (2010), Literatura polska 1939-2009, Wydawnictwo Naukowe PWN, Warszawa.

Czapliński Przemysław (2011), Przyszła teraźniejszość, w: tegoż, Resztki nowoczesności. Dwa studia o literaturze i życiu, Wydawnictwo Literackie, Kraków, s. 231-242. Dukaj Jacek (2010), Linia oporu, w: tegoż, Król bólu, Wydawnictwo Literackie, Kraków, s. 5-227.

Dukaj Jacek (2014), Perfekcyjna niedoskonałość. Pierwsza Tercja Progresu, wyd. 2, Wydawnictwo Literackie, Kraków. 
Handke Ryszard (1989), Językowe spory kreowania składników fantastycznych, w: Spór o SF. Antologia szkiców i esejów o science fiction, red. Ryszard Handke, Lech Jęczmyk, Barbara Okólska, Wydawnictwo Poznańskie, Poznań, s. 225-239. Jadacka Hanna (2005), Kultura języka polskiego. Fleksja, słowotwórstwo, składnia, Wydawnictwo Naukowe PWN, Warszawa.

Kobielska Maria (2010), Neoludzkim głosem (Extensa), w: Splot, http://www.esplot. pl/?pid=articles\&id=542 [dostęp: 15 maja 2017].

Kurkowska Halina, Skorupka Stanisław (2001), Stylistyka polska. Zarys, wyd. 5 uzup., Wydawnictwo Naukowe PWN, Warszawa.

Markowski Andrzej (2005), Kultura języka polskiego. Teoria. Zagadnienia leksykalne, Wydawnictwo Naukowe PWN, Warszawa.

Markowski Andrzej, red. (2004), Wielki słownik poprawnej polszczyzny, Wydawnictwo Naukowe PWN, Warszawa.

Podstawa programowa kształcenia ogólnego dla czteroletniego liceum ogólnoksztatcacego i pięcioletniego technikum (2018), https://www.gov.pl/web/edukacja/nowapodstawa-programowa-dla-liceum-technikum-i-branzowej-szkoly-ii-stopniapodpisana [dostęp: 31 grudnia 2018].

Postludzki, w: Narodowy Fotokorpus Języka Polskiego, http://nfjp.pl/lemma/postludzki [dostęp: 22 października 2017].

Słownik języka polskiego, Wydawnictwo Naukowe PWN, http://sjp.pwn.pl/ [dostęp: 22 października 2017].

Tako rzektu phoebe (2010), w: Język mnie zachwyca, http://jezykmniezachwyca.blogspot.com/2010/11/tako-rzeku-phoebe.html [dostęp: 30 października 2017].

Ilona Mikołajczak

\section{Artistic neologisms as subject of research of linguistic corectness}

The purpose of this study was to present the conclusions about checking artistic neologisms for lingustic corectness. The article begins the review of contemporary source literature that gradually eliminate fiction from resarch on linguistic corectness, in spite of long-standing tradition of using literary works. Then the author passes on a detailed analysis of criteria of linguistic corectness developed by Warsaw School of Lingustics, chosing Jacek Dukaj's prose as subject of resarch and defending this choice. Futhermore, excerpts the fulfiling the criteria examples or not, also raises the questions of usefulness of all the criteria and the reference to category of literary genre, and what can be the mistake in fiction. The effect of this investigation is new hierarchical compilation of linguistic corectness criteria, created for the purposes of the codification. 
KEYWORDS: linguistic codification, criteria of linguistic corectness, neologisms, Jacek Dukaj.

mgr Ilona Mikołajczak - doktorantka w Instytucie Filologii Polskiej Uniwersytetu im. Adama Mickiewicza w Poznaniu; zainteresowania badawcze: tendencje rozwojowe współczesnej polszczyzny, zagadnienia normatywistyki językowej. 